\title{
Caregiving as Moral Experience
}

\section{Citation}

Kleinman, Arthur. 2012. Caregiving as Moral Experience. The Lancet 380(9853): 1550-1551.

\section{Published Version}

doi:10.1016/S0140-6736(12)61870-4

\section{Permanent link}

http://nrs.harvard.edu/urn-3:HUL.InstRepos:10718375

\section{Terms of Use}

This article was downloaded from Harvard University's DASH repository, and is made available under the terms and conditions applicable to Open Access Policy Articles, as set forth at http:// nrs.harvard.edu/urn-3:HUL.InstRepos:dash.current.terms-of-use\#OAP

\section{Share Your Story}

The Harvard community has made this article openly available.

Please share how this access benefits you. Submit a story.

\section{Accessibility}


Caregiving-as-Moral-Experience-Lancet-FIRST-SUBMISSION-October-10-2012.docx

Edited Thursday October 11, 2012. Submitted to The Lancet on 10-10-2012WORD count 1729 (excluding references)

File: (R drive: Kleinman papers folder, Lancet folder: Caregiving-as-Moral-Experience-Lancet-FIRSTSUBMISSION-October-10-2012.docx

Caregiving as Moral Experience: The Limits of Economics and the Responsibilities of Medicine

Arthur Kleinman

Harvard University 
Caregiving-as-Moral-Experience-Lancet-FIRST-SUBMISSION-October-10-2012.docx

Edited Thursday October 11, 2012. Submitted to The Lancet on 10-10-2012WORD count 1729 (excluding references)

kleinman@wjh.harvard.edu

The Moral Limits of Economics in Health Care

Everyone who has been in love or built a family knows that there are things, essential

things, that money can't buy. Patients with serious illness and their network of caregivers know

this too, because those things that really matter to us are threatened and must be defended. And

many clinicians, reflecting on what is at stake in health care not only for patients but for 
themselves, know the same thing: the market has an important role in health care financing and health systems reform, but it cannot and should not reach into those quintessentials of caregiving that speak to what is most deeply human in medicine and in living. This is the moral limit of an economic paradigm. Or at least it should be.

But we live in a truly confused age. The market model has infiltrated so thoroughly into human lives and medicine that in certain circles - policy making and analysis, hospital and clinic administration, and, to a degree that would have shocked us 50 years ago, clinical workeconomic rationality with its imperative of containing costs and maximizing efficiency has come to mute the moral, emotional, religious and aesthetic expressions of sufferers and caregivers.

Most take it for granted and accept its implications. Simplistic models from economic 
psychology, behavioral economics and business studies, based on the narrowest calculations of

what a 'rational man' (or woman) would choose as most cost effective, are now routinely applied

to clinical decision-making and the organization of care. They model the choices available to

patients and their family members, as if they were sufficient for the torturous experience at end-

of-life, the routine frustrating crises that constitute caregiving for neurodegenerative conditions,

the admixture of desperation that depression brings to disabling heart disease and cancers, and

the emotional turmoil and challenges to our values of serious childhood disabilities. Such

models, pace the claims to the contrary of health policy experts and program administrators, are

themselves value-laden, and once introduced, warp the context of health care - a kind of

gravitational field that attracts the instrumental and distorts the human. 
Professionals and laypersons may rail against the hubris of the market model in

caregiving, and yet in current debates over health care reform in the U.S., the U.K, China, and

many other countries, neither the voices of clinical professionals nor those of family caregivers

are invited or adequately heard, let alone carry equal weight. Nor do abiding concerns over social

justice for people in deep poverty or doing good in the world for the sake of the most vulnerable

and those in great distress seem to mobilize the power of persuasion and calling that those of us

who came of age in the 1950s and 1960s remember.

This is not just an issue of the corrosive effect of unbridled capitalism on human values

which Marx inveighed against, albeit it is partly that. It is also a stunning failure of people who

have skin in the game, which means pretty nearly all of us, to adequately articulate and champion 
an alternative. In caregiving, I believe there is an alternative that makes the case for the limits of

markets and also offers a different vision; because caregiving in and of itself is one of the

foundational moral meanings and practices in human experience everywhere, defining human

value that resists crude reduction to counting and costing.

Caregiving as Human Value and Moral Practice

Consider how central caregiving is to what it means to be human. Caregiving is an

indelible part of relations between partners, the raising of children, and response to the

infirmities of aged parents and grandparents. It is, of course, the very definition of how families 
and friendship networks cope with sickness or disability among their own. And there is an

ancient lineage to caregiving across historical periods and societies. Nursing, medicine, and the

allied health disciplines justify their status as healing professions by underlining their

professional commitment to caregiving. Religions respond to suffering with rituals that animate

caregiving in both social and subjective realms. All cultures have elaborate systems of healing

and ideas about illness and its courses and treatment which are enacted in the care of the sick. Of

course, the sensibility of caregiving extends well beyond medicine to stewardship of the

environment, support for the welfare of the poor, and to the building of political institutions and

processes that advance basic human interests. 
To be sure, the moral distance between stated values and actual practices is substantial.

Over the last several years, when I have delivered lectures at a number of medical schools and

health science centers, I have explained to the audience that, given how little in the way of

financial, time-in-the-curricula, and other resources most medical schools devote to the

principles, values and practice of caregiving, perhaps we should allow medical schools to

remove caregiving as a goal of medical education and restrict the curriculum to technical clinical

competence and biomedical knowledge. The response in the question and answer period is

usually dozens of hands that go up and are followed by passionate defense of how important

caregiving is to medicine, and I adduce to their own sense of purpose and meaning. 
So in light of this seeming paradox-medicine invests little in caregiving, yet it is core to

health professionals' motivations and identity_how should we think of caregiving?

For family members, close friends, the sufferers themselves and professionals caregiving

turns on the amelioration of pain and suffering. Practical assistance with activities of daily

living — feeding, bathing, ambulating, toileting — is a basic component, as are protection and

emotional support. For physicians, in particular, diagnosis, prognosis, treatment and

rehabilitation can be carried out in ways that emphasize their human as well as their technical

aspects, both of which are part of caregiving.

But here I wish to emphasize the moral face of caregiving. Acknowledgement of the

personhood of sufferers and affirmation of their condition and struggle have long been 
recognized as the most basic and sustaining of moral acts, whether among the friendship and kin network or in patient-physician and other professional relationships. The laying on of hands, empathic witnessing, listening to the illness narrative, providing moral solidarity through sustained engagement and responsibility over the course of chronicity and in the terminal period - all are core moral tasks in caregiving. Theorists of caregiving have also identified "presence" - being there, existentially, even when nothing practical can be done and hope itself is eclipsed - as central to the giving of care. And it is also important in care receiving, because caregiving is almost always a deeply interpersonal, relational practice which resonates with the most troubling preoccupations of both carer and sufferer about living, about self and about dignity. 
In anthropological terms, caregiving centers on a different kind of reciprocity than

financial exchanges--albeit it can be both. It is closer to gift giving and receiving among people

whose relationships really matter. The person receiving care shares her experience and story as a

gift with the caregiver, in reciprocation for the practical things that need doing along with a

sensibility akin to love. What is exchanged is the moral responsibility, emotional sensibility and

social capital of the relationship. The exchange changes the subjectivity of the caregiver and

carereceiver. The terms "taking care" and "caring" imply cultivation of the person and the

relationship through practices of attending, enacting, supporting and collaborating. What is at

stake is doing good, for others and for one self, if need be, in spite of the emotional and material

cost. Indeed, the rewards, unvoiced or explicit, can be transformative, going to the heart of who

we are and what we can offer, or endure. 
Inasmuch as caregiving (and receiving) is carried out by individuals who themselves are complex and divided and who inhabit local worlds that are also plural and divided, it needs to be understood as a process that is affected by emotional, political and economic realities. But that does not mean that the market is more fundamental than caregiving. They are often entangled to be sure, but they are also distinctive ways of being human as well as different visions of who we are.

The great failure of contemporary medicine to promote caregiving as an existential practice and moral vision that resists reduction to the market model or the clarion call of efficiency has diminished professionals, patients and family caregivers alike. It has enabled a 
noisy and ubiquitous market to all but silence different motives, ideals, hopes and behaviors that

must be expressed, because they are as much who we are as economic rationality. Absent

caregiving from the political and economic discourse on health care, and nothing but institutional

and monetary issues come to matter. Even questions of "quality" in health care become distorted.

What counts as "evidence", then, is an absence of presence. Caregiving with its central

commitments to doing good to others and to oneself becomes invisible and is left out of the

debates on policies and programs. And the result is that all of us are demeaned and the profession

of medicine and the processes of health care are transmuted into something that is hollowed of its

humanity and moral value. And yet throughout health organizations, in medical wards, in clinics,

in ambulances and emergency facilities, in managers' offices, in endless meetings, clinical

conferences, and quality-of-life care committees are individuals for whom the calling and the 
passion for caregiving is alive. They know the power of a touch, true listening, the quiet

satisfaction of making a difference. The system is not the people (mostly) in it.

This is a call, therefore, for a serious discussion about caregiving and a reconsideration of

its place in medical education, medical practice, and medical research, on the one side, and its

significance for patients, families, and communities, on the other. Nor should this discussion be

restricted to health care. Once we open the door to the democratic implications of caregiving as

moral and political practices, so much of the rest of our world from leadership to governance and

from domestic to foreign affairs becomes a matter not just of markets, regulations, and security

concerns, but of how we can enact care as humankind's shared project. 
Caregiving-as-Moral-Experience-Lancet-FIRST-SUBMISSION-October-10-2012.docx

Edited Thursday October 11, 2012. Submitted to The Lancet on 10-10-2012WORD count 1729 (excluding references)

Readings:

Georges Canguilhem: Writings on Medicine. Translated by Stefanos Geroulanos and Todd

Meyers. N.Y.: Fordham University Press, 2012.

Arthur Kleinman: The Illness Narratives. New York: Basic Books, 1988

Arthur Kleinman: What Really Matters. Oxford and New York: Oxford University Press, 2006.

Annemarie Mol: The Logic of Care. New York: Routledge, 2008. 
Caregiving-as-Moral-Experience-Lancet-FIRST-SUBMISSION-October-10-2012.docx

Edited Thursday October 11, 2012. Submitted to The Lancet on 10-10-2012WORD count 1729 (excluding references)

Michael J. Sandel: What Money Can't Buy. New York: Farrar, Straus and Giroux, 2012

Joan Tronto: Moral Boundaries: A Political Argument for an Ethics of Care. New York:

Routledge, 1993. 